\begin{tabular}{l} 
Efficient $\mathrm{Vol} 3$ (1) (2020): 710 -718 DOI: https://doi.org/10.15294/efficient.v3i1.35972 \\
$\begin{array}{c}\text { Indonesian Journal of Development Economics } \\
\text { https://journal.unnes.ac.id/sju/index.php/efficient }\end{array}$ \\
\hline
\end{tabular}

\title{
Faktor-Faktor yang Mempengaruhi Pengeluaran Listrik Rumah Tangga
}

\author{
Sigit Dwi Purnomo' \\ Jurusan Ekonomi Pembangunan, Fakultas Ekonomi, Universitas Negeri Semarang \\ Permalink/DOI: https://doi.org/10.15294/efficient.v3i1.35972 \\ Received: July 2019 ; Accepted: October 2019 ; Published: January 2020

\begin{abstract}
The condition of the national electricity this center is experiencing a crisis as a result of the surge in demand for electricity is greater than the level of supply. Including for household electricity. The purpose of this study was to determine and analyze the effect of a variable number of electronic goods, household size, amount of space, the building area of the house, and family income over expenditure of household electricity in the village Sekaran, Gunungpati subdistrict, Semarang city. Household electricity expenditure as the dependent variable, while the number of electronic goods, household size, amount of space, the building area of the house, and family income as the independent variable. The method used is multiple linear regression analysis. The results of this study indicate that a variable number of electronic goods, the number of family members, house building area, family income positive effect and significant on household electricity expenditures in the village Sekaran. While the variable amount of space did not affect the household electricity expenditures in the village Sekaran.
\end{abstract}

Keywords: Factors Electrical Household Spending.

\section{Abstrak}

Kondisi ketenagalistrikan nasional sat ini sedang mengalami krisis sebagai akibat terjadinya lonjakan permintaan akan listrik yang lebih besar dibanding tingkat pasokannya. Termasuk untuk listrik rumah tangga. Tujuan penelitian ini adalah untuk mengetahui dan menganalisis pengaruh variabel jumlah barang elektronik, jumlah anggota keluarga, jumlah ruang, luas bangunan rumah, dan pendapatan keluarga terhadap pengeluaran listrik rumah tangga di Kelurahan Sekaran, Kecamatan Gunungpati, Kota Semarang. Pengeluaran listrik rumah tangga sebagai variabel dependennya, sedangkan jumlah barang elektronik, jumlah anggota keluarga, jumlah ruang, luas bangunan rumah, dan pendapatan keluarga sebagai variabel independennya. Metode yang digunakan adalah analisis regresi linier berganda. Hasil dari penelitian ini menunjukkan bahwa variabel jumlah barang elektronik, jumlah anggota keluarga, luas bangunan rumah, pendapatan keluarga berpengaruh positif dan signifikan terhadap pengeluaran listrik rumah tangga di Kelurahan Sekaran. Sedangkan variabel jumlah ruang tidak berpengaruh terhadap pengeluaran listrik rumah tangga di Kelurahan Sekaran..

\section{Kata Kunci: Faktor-Faktor Pengeluaran Listrik Rumah Tangga.}

How to Cite: Purnomo, S. (2020). Faktor-Faktor yang Mempengaruhi Pengeluaran Listrik Rumah Tangga. Efficient: Indonesian Journal of Development Economics, $3(1), \quad 710-718$. https://doi.org/10.15294/efficient.v3i1.35972

(C) 2019 Semarang State University. All rights reserved

\footnotetext{
Alamat Korespondensi :

Alamat: Gedung L2 Lantai 2 FE Unnes

Kampus Sekaran, Gunungpati, Semarang, 50229

E-mail : efficientjournal@gmail.com
}

ISSN 2655-6197 


\section{PENDAHULUAN}

Kondisi ketenagalistrikan nasional pada saat ini sedang mengalami krisis (scarcity problem) sebagai akibat terjadinya lonjakan permintaan akan listrik yang lebih besar dibanding tingkat pasokannya. Data statistik kelistrikan PLN Indonesia pada tahun 2010, menunjukan bahwa laju pertumbuhan produksi rata-rata energi listrik (supply) hanya mencapai 6,17 persen per tahun sepanjang tahun 2000-2010, sedangkan laju pertumbuhan permintaan rata-rata energi listrik (demand) pada periode yang sama mencapai 6,41 persen per tahun. Selain itu dengan mempertimbangkan asumsi pertumbuhan ekonomi nasional rata-rata tumbuh sebesar 6,1 persen pertahun dan pertumbuhan penduduk secara nasional tumbuh sebesar 1,3 persen pertahun, perkiraan kebutuhan tenaga listrik nasional sesuai Rencana Umum Ketenagalistrikan Nasional 2008-2027 diperkirakan akan mencapai rata-rata sebesar 9,2 persen per tahun (Master Plan Pembangunan Ketenagalistrikan 2010-2014 KESDM, 2009:13). Melihat keberadaan energi listrik yang sangat vital dalam mendorong roda pembangunan, maka tidak dapat disangsikan lagi bahwa laju permintaan energi listrik diperkirakan akan terus meningkat pada tahun mendatang. Hal ini terjadi karena usaha penyediaan energi listrik cenderung tetap atau statis karena masih minimnya investasi untuk penambahan sumber-sumber baru penyediaan tenaga listrik.

PLN melakukan pengggolongan terhadap konsumennya berdasarkan besarnya tarif listrik yang dikenakan, dalam penggolongan listrik untuk aktivitas sektor ekonomi dapat dibagi menjadi 4 (empat) kelompok yaitu: 1) Rumah Tangga, 2) Usaha, 3) Industri dan 4) Pemerintahan atau publik. Rumah tangga adalah kelompok pelanggan yang menggunakan listrik sebagai salah satu energi yang dipakai dalam memenuhi kebutuhannya. Kelompok usaha terdiri dari usaha. penginapan, rumah makan, perdagangan, jasa keuangan, jasa hiburan dan jasa sosial. Kelompok industri berupa beberapa industri. Berikut data Penjualan listrik pelanggan PT. PLN di Jawa tenggah tahun 21014(MWh).

Tabel 1. Penjualan Listrik Pelanggan PT. PLN Di Jawa Tengah Tahun 2014 (MWh)

\begin{tabular}{llllllll}
\hline No & Unit PLN & $\begin{array}{l}\text { Rumah } \\
\text { Tangga }\end{array}$ & Industri & Usaha & Sosial & $\begin{array}{l}\text { Kantor } \\
\text { Pemerintahan }\end{array}$ & $\begin{array}{l}\text { Penerangan } \\
\text { Jalan }\end{array}$ \\
\hline 1. & Semarang & 1753642 & 1779028 & 703581 & 194284 & 80921 & 75193 \\
2. & Surakarta & 1367693 & 2216815 & 429383 & 115181 & 27689 & 84822 \\
3. & Kudus & 1325620 & 627878 & 211470 & 73815 & 21485 & 53811 \\
4. & Tegal & 1187473 & 98393 & 175162 & 48906 & 12750 & 48533 \\
Jumlah & & 563448 & 4722114 & 1519596 & 432186 & 142845 & 262359 \\
\hline
\end{tabular}

Sumber : Badan Pusat Statistik, 2015. 
Tabel 1 dapat diketahuai bahwa penggunaan listrik yang paling besar adalah sektor rumah tangga dan industri. Unit PLN yang paling banyak mengkonsumsi listrik adalah Semarang untuk sektor rumah tangga sebesar 1.753.642 MWh dan sektor industri yaitu 1.779.028 MWh. Dan di ikuti oleh Surakarta untuk sektor rumah tangga sebesar 1.367.693 MWh dan sektor industri sebesar 2.216.815 MWh. Kudus menempati urutan 3 dimana sektro rumah tangga 1.325.620 MWh dan insustri sebesar 627.878 MWh. Terakhir Tegal untuk sektor rumah tangga $\mathbf{1 . 1 8 7 . 4 7 3}$ MWh sebesar dan industri sebesar 98.393 MWh.

Pertumbuhan permintaan listrik konsumen sektor rumah tangga ke depan akan terus meningkat sesuai dengan hasil proyeksi kebutuhan listrik dari tahun 2003-2020 yang dilakukan Dinas Perencanaan Sistem PT PLN (Persero) dan Tim Energi BPPT, terlihat bahwa selama kurun waktu tersebut rata-rata kebutuhan listrik di Indonesia tumbuh sebesar $6,50 \%$ per tahun dengan pertumbuhan listrik disektor rumah tangga sebesar 6,90\% per tahun, sehingga potensi permintaan dan penggunaan listrik rumah tangga masih cukup besar. Karena penyiapan sarana pembangkitan perlu waktu yang lebih lama, maka perencanaan pelayanan permintaan harus melihat jangka pendek, jangka menengah maupun jangka panjang. Dalam hal ini penting untuk melakukan kajian terhadap variabel yang mempengaruhi permintaan atau pengguanaan listrik konsumen di sektor rumah tangga agar memudahkan manajemen memproyeksi permintaan listrik konsumen sektor rumah tangga dan menyiapkan langka strategis secara terpadu dalam menyiapkan sistem pelayanan.

Berdasarkan penggolongan konsumen listrik yang di lakukan oleh PLN, maka kelompok rumah tangga berada yang terbesar dalam penggunaan listrik, serta memungkinkan kota-kota besar mengkonsumsi listrik yang besar seperti data pada tabel 1.2 yaitu kota besar Semarang menjadi konsumen terbesar penggunaan listrik sektor rumah tangga yaitu sebesar 1.753 .642 MWh. Data observasi penelitian berada di Kelurahan Sekaran, Kecamatan Gunungpati, Kota Semarang pada bulan pertengahan maret hingga akhir april 2016 menunjukkan pemadaman listrik sebanyak 6 kali. Selain itu di Kota Semarang laporan mengenai gangguan listrik pada tahun 2016 (BPS) sebesar 1.144 laporan mengenai berbagai gangguan listrik. Pemadaman serta gangguan listrik tersebut mencerminkan tingkat pemenuhan konsumsi listrik rumah tangga masih ada kendala di kota besar seperti Semarang sebagai Ibu Kota Jawa Tengah. Selain itu di Keluarahan Sekaran ini ada Universitas Negeri di mana penambahan jumlah mahasiswa yang tinggal sementara di kos-kosan selama kuliah, akan mempengaruhi penambahan penggunaan listrik khususnya sektor rumah tangga. Berdasarkan pertimbangan tersebut maka pengambilan daerah penelitian yaitu di Kelurahan Sekaran, Kecamatan Gunungpati, Kota Semarang.

Permintaan atau penggunaan listrik rumah tangga juga dipengaruhi oleh variabelvariabel, seperti: harga (tarif), pendapatan, harga barang lain, banyaknya peralatan listrik yang digunakan, harga peralatan listrik yang digunakan, waktu beban puncak, tingkat 
kegiatan ekonomi, luas bangunan rumah, iklim dan Faktor sosial lainnya (Kadir, 2000). Faktor-faktor Pengeluaran Listrik rumah tangga dalam penelitian ini antara lain : jumlah barang elektronik, jumlah anggota keluarga, jumlah ruang, luas bangunan rumah, dan pendapatan keluarga.

Tujuan penelitian ini adalah untuk mengetahui dan menganalisis pengaruh jumlah anggota keluarga, luas bangunan rumah, pendapatan keluarga, jumlah barang elektronik, jumlah ruang terhadap pengeluaran listrik rumah tangga di Kelurahan Sekaran, Kecamatan Gunungpati, Kota Semarang.

\section{METODE PENELITIAN}

Penelitian ini menggunakan pendekatan kuantitatif. Pendekatan kuantitatif dituntut menggunakan angka mulai dari pengumpulan, penafsiran serta hasilnya.

Populasi dalam penelitian ini adalah jumlah penduduk kelurahan sekaran sebesar 6.593 (BPS, 2015). Penarikan sampel yang digunakan dalam penelitian ini menggunakan metode probability sampling, yaitu semua anggota atau subjek penelitian memiliki peluang yang sama untuk dipilih sebagai sampel. Dalam hal ini, sampel dianggap mewakili populasi karena memiliki kesamaan karakteristik, ciri, sifat tertentu berupa karakter sebagai pengguna listrik di Kelurahan Sekaran. Teknik pengambilan sampel pada penelitian ini yaitu menggunakan teknik simple random sampling. Simple random sampling adalah teknik pengambilan sampel secara acak tanpa memperhatikan strata yang ada dalam pupulasi tersebut (Sugiyono, 2001).

Variabel dependen penelitian ini adalah pengeluaran listrik di Kelurahan Sekaran.
Pengeluaran listrik merupakan jumlah jumlah tagian listrik rumah tangga yang dibayarkan kepada PLN selama satu bulan dengan satuan rupiah.

Variabel independen yang digunakan dalam penelitian ini adalah jumlah barang listrik adalah banyaknya barang elektronik atau alat-alat yang menggunakan tenaga listrik dalam penggunaannya satuan unit, jumlah anggota keluarga adalah banyaknya anggota keluarga atau pun orang lain yang tinggal menetap dalam satu rumah tangga dinyatakan dalam satuan orang, jumlah ruang adalah banyaknya ruang dalam rumah satuan unit, luas bangunan adalah luas rumah yang dihuni oleh keluarga diukur dengan satuan meter persegi, pendapatan keluarga adalah seluruh pendapatan perbulan dari suami, istri, anak, maupun saudara yang mempunyai penghasilan serta tinggal menetap dalam rumah tersebut, baik itu pekerjaan utama maupun sampingan yang menjadi sumber penghidupan keluarga satuan rupiah per bulan.

Data primer diperoleh dari hasil wawancara dengan panduan kuesioner kepada responden pengguna listrik rumah tangga di kelurahan Sekaran yang berjumlah 100 orang. Data skunder diperoleh dari dokumen, catatan, jurnal dan situs internet yang dimiliki dinas atau instansi terkait.

Metode wawancara digunakan untuk mencari data primer yang dibutuhkan dalam penyusunan penelitian ini. Metode wawancara dilakukan kepada 100 responden pelanggan listrik rumah tangga yang dilaksanakan pada bulan oktober sampai dengan november 2016. Metode dokumentasi digunakan untuk mencari data skunder dari dokumen, catatan, jurnal dan situs internet yang diperoleh dari 
BPS Jawa Tengah dan BPS kecamatan Gunungpati. Serta untuk mendapatkan datadata sekunder, seperti data-data rumah, tipe rumah, dan data-data sekunder lainnya maka dilakukan penelitian terhadap dokumen yang diperlukan.

Model matematis fungsi Pengeluaran listrik rumah tangga dengan metode regresi berganda, sebagai berikut :

$\ln C=\beta_{o}+\beta_{1} \ln X_{1}+\beta_{2} \ln X_{2}+\beta_{3} \ln X_{3}+\beta_{4} \ln X_{4}+\beta_{5}$ $\ln \mathrm{X}_{5}+\mu$.

Dimana:

$\ln C \quad:$ Pengeluaran listrik rumah tangga (rupiah)

Bo : konstanta

$\beta_{1}, \ldots . \beta_{5} \quad: \quad$ koefisien regresi variabel $\mathrm{X}_{1}, \ldots . \mathrm{X}_{5}$

$\ln \mathrm{X}_{1} \quad$ : Jumlah Barang Elektronik (unit)

(unit)

$\ln X_{2} \quad: \quad J u m l a h$ Anggota Keluarga (orang)

$\ln X_{3} \quad:$ Jumlah Ruang (unit)

$\ln \mathrm{X}_{4} \quad$ : Luas Bangunan Rumah (meter persegi)

$\ln \mathrm{X}_{5} \quad:$ Pendapatan Keluarga (rupiah)

$\mu \quad$ : Standar Eror

Model persamaan regresi linier berganda dengan pendekatan Ordinary Least Square (OLS) digunakan untuk mengetahui besar pengaruh antara variabel independen terhadap variabel dependen konsumsi listrik di Kelurahan Sekaran. Hasil penelitian yanjg dilakukan kepada 100 pengguna/pelanggan listrik rumah tangga di Kelurahan Sekaran dengan bantuan alat analisis EViews 9.

Mengambil kesimpulan berdasarkan hasil regresi, maka model persamaan harus terbebas dari penyimpangan asumsi klasik. Dalam penelitian ini dilakukan pengujian multikolinearitas, heteroksedastisitas dan uji normalitas. Uji autokorelasi tidak dilakukan karena data cross section diduga jarang ditemui adanya unsur autokorelasi (Widarjono, 2007:155). Serta dalam mengolah data dengan regresi harus melakukan uji statistik terdiri dari: Uji F-Statistik, Uji Koefisien Determinasi (R2), uji t-Statistik.

\section{HASIL DAN PEMBAHASAN}

Berdasarkan hasil regresi, maka model ekonometrika yang dihasilkan yaitu sebagai berikut:

$$
\begin{aligned}
& \text { Model } \quad: \ln C=\beta_{0}+\beta_{1} \ln \mathrm{X}_{1}+\beta_{2} \ln \mathrm{X}_{2} \\
& +\beta_{3} \ln X_{3}+\beta_{4} \ln X_{4}+\beta_{5} \ln X_{5}+ \\
& \mu \text {.. } \\
& +0,376344 \ln \mathrm{PK}+\mu
\end{aligned}
$$

Keterangan :

LnC : Pengeluaran listrik rumah tangga (rupiah)

$\beta_{1} \ln X_{1} \quad$ : Jumlah Barang Elektronik (unit)

$\beta_{1} \ln X_{2}$ : Jumlah Anggota keluarga (orang)

$\beta_{1} \ln X_{3}$ : Jumlah Ruang (unit)

$\beta_{1} \ln X_{4}$ : Luas Bangunan Rumah (meter persegi)

$\beta_{1} \ln X_{5}$ : Pendapatan keluarga (rupiah)

$\mu \quad$ : Standar Eror

Nilai koefisien jumlah barang elektronik untuk variabel (X1) adalah sebesar o,396485. Hal ini dapat diartikan bahwa setiap kenaikan jumlah barang elektronik sebesar 1 unit maka pengeluaran listrik rumah tangga naik sebesar 
0,396485 rupiah per bulan, begitupun sebaliknya jika jumlah barang elektronik turun sebesar 1 unit, maka pengeluaran listrik rumah tangga turun sebesar 0,396485 rupiah per bulan. (Asumsi bahwa variabel bebas yang lain dari model regresi tetap).

Nilai koefisien jumlah anggota keluarga untuk variabel (X2) adalah sebesar 0,286925. Hal ini dapat diartikan bahwa setiap penambahan jumlah keluarga sebesar 1 orang, maka pengeluaran listrik rumah tangga naik sebesar 0,286925 rupiah per bulan, begitupun sebaliknya jika jumlah anggota keluarga turun sebesar 1 orang, maka pengeluaran listrik rumah tangga turun sebesar o,286925 rupiah per bulan. (Asumsi bahwa variabel bebas yang lain dari model regresi tetap).

Nilai koefisien jumlah ruang untuk variabel $\left(\mathrm{X}_{3}\right)$ adalah sebesar 0,158763. Hal ini dapat diartikan bahwa setiap penambahan jumlah ruang sebesar 1 unit, maka pengeluaran listrik rumah tangga naik sebesar o,158763 rupiah per bulan, begitupun sebaliknya jika jumlah ruang turun sebesar 1 unit, maka pengeluaran listrik rumah tangga turun sebesar 0,158763 rupiah per bulan. (Asumsi bahwa variabel bebas yang lain dari model regresi tetap).

Nilai koefisien luas bangunan rumah untuk variabel $\left(\mathrm{X}_{4}\right)$ adalah sebesar 0,390251. Hal ini dapat diartikan bahwa setiap penambahan luas bangunan rumah sebesar 1 $\mathrm{m}^{2}$, maka pengeluaran listrik rumah tangga naik sebesar 0,390251 rupiah per bulan, begitupun sebaliknya jika luas bangunan rumah turun sebesar $1 \mathrm{~m}^{2}$, maka pengeluaran listrik rumah tangga turun sebesar 0,390251 rupiah per bulan. (Asumsi bahwa variabel bebas yang lain dari model regresi tetap). Sedangkan nilai koefisien pendapatan keluarga untuk variabel $\left(\mathrm{X}_{5}\right)$ adalah sebesar 0,376344 . Hal ini dapat diartikan bahwa setiap penambahan pendapatan sebesar 1 rupiah, maka pengeluaran listrik rumah tangga naik sebesar 0,376344 rupiah per bulan, begitupun sebaliknya jika pendapatan keluarga turun sebesar 1 rupiah, maka pengeluaran listrik rumah tangga turun sebesar o,376344 rupiah per bulan. (Asumsi bahwa variabel bebas yang lain dari model regresi tetap).

\section{Uji Statistik}

Uji F-Statistik adalah dimaksudkan untuk membuktikan secara statistik bahwa seluruh variabel independen (bebas) berpengaruh secara bersama-sama terhadap variabel dependen (terikat) yaitu pengeluaran listrik rumah tangga di Kelurahan Sekaran, dengan hipotesis untuk menunjukkan apakah seluruh variabel bebas yang dimaksudkan dalam model mempunyai pengaruh secara bersama-sama terhadap variabel terikat dengan menggunakan hasil regresi utama. hasil penelitian menunjukkan bahwa $\mathrm{F}$ hitung sebesar 2,636493 sedangkan $F$ tabel yang diperolah sebesar 2,31. Oleh karena itu F hitung > F tabel yaitu 2,636493 > 2,31 maka Ho ditolak dan Ha diterima atau secara bersamasama variabel independen secara signifikan mempengaruhi variabel dependen secara nyata.

Uji Koefisien Determinasi (R2) pada intinya mengukur seberapa jauh kemampuan model dalam menerangkan variasi variabel dependen. R2 bertujuan untuk mengetahui seberapa jauh variasi variabel independen menerangkan dengan baik variasi variabel dependen. Model yang baik adalah model yang meminimumkan residual berarti variasi variabel independen dapat menerangkan 
variabel dependennya (Gujarati, 2012), sehingga diperoleh korelasi yang tinggi antara variabel dependen dan variabel independen. Hasil penelitian menunjukkan nilai R-squared atau R2 sebesar o,583748 (58,37\%). Hal ini berarti variabel bebas jumlah barang elektronik, jumlah anggota keluarga, jumlah ruang, luas bangunan rumah, pendapatan keluarga mampu menjelaskan pengeluaran listrik rumah tangga sebanyak $58,37 \%$ dan sisanya dijelaskan oleh variabel dilain model regresi. Uji statistik t pada dasarnya bertujuan untuk melihat seberapa besar pengaruh dari variabel penjelas/independen secara individual dalam menerangkan variasi variabel dependen (Ghozali, 2011). Pengujian signifikansi koefisien regresi secara parsial dapat menggunakan uji $t$ (t-test). hasil pengujian statistik $\mathrm{t}$ sebagai berikut:

\section{Jumlah barang elektronik}

Berdasarkan hasil regresi diperoleh nilai t-hitung $=2,514891$ dan diperoleh $\mathrm{t}$-tabel $=$ 1,661, sehingga diperoleh hasil t-hitung sebesar 2,514891< t-tabel 1,661, maka keputusannya adalah hipotesis nol (Ho) ditolak dan hipotesis (Ha) diterima. Hasil dari uji $t$ tersebut menyatakan bahwa jumlah barang elektronik memiliki pengaruh yang positif terhadap pengeluaran listrik rumah tangga di Kelurahan Sekaran. Sesuai dengan hipotesis dan signifikian secara statistik, sehingga dapat dinyatakan bahwa jumlah barang elektronik memiliki pengaruh secara nyata terhadap pengeluaran listrik rumah tangga di Kelurahan Sekaran.

\section{Jumlah Anggota Keluarga}

Berdasarkan hasil regresi diperoleh nilai t-hitung $=1,841801$ dan diperoleh $\mathrm{t}$-tabel $=$
1,661, sehingga diperoleh hasil t-hitung sebesar 1,841801> t-tabel 1,661, maka keputusannya adalah hipotesis nol (Ho) ditolak dan hipotesis (Ha) diterima. Hasil dari uji $t$ tersebut menyatakan bahwa jumlah anggota keluarga memiliki pengaruh yang positif terhadap pengeluaran listrik rumah tangga di Kelurahan Sekaran. Sesuai dengan hipotesis dan signifikian secara statistik, sehingga dapat dinyatakan bahwa jumlah anggota keluarga memiliki pengaruh secara nyata terhadap pengeluaran listrik rumah tangga di Kelurahan Sekaran.

\section{Jumlah Ruang}

Berdasarkan hasil regresi diperoleh nilai t-hitung = 0,720941 dan diperoleh t-tabel = 1,661, sehingga diperoleh hasil t-hitung sebesar o,720941< t-tabel 1,661, maka keputusannya adalah hipotesis nol (Ho) diterima dan hipotesis (Ha) ditolak. Hasil dari uji t tersebut menyatakan bahwa jumlah ruang tidak memiliki pengaruh terhadap pengeluaran listrik rumah tangga di Kelurahan Sekaran.

\section{Luas Bangunan Rumah}

Berdasarkan hasil regresi diperoleh nilai t-hitung $=2,984899$ dan diperoleh t-tabel = 1,661, sehingga diperoleh hasil t-hitung sebesar 2,984899> t-tabel 1,661, maka keputusannya adalah hipotesis nol (Ho) ditolak dan hipotesis (Ha) diterima. Hasil dari uji $t$ tersebut menyatakan bahwa luas bangunan rumah memiliki pengaruh yang positif terhadap pengeluaran listrik rumah tangga di Kelurahan Sekaran. Sesuai dengan hipotesis dan signifikian secara statistik, sehingga dapat dinyatakan bahwa luas bangunan rumah memiliki pengaruh secara nyata terhadap 
pengeluaran listrik rumah tangga di Kelurahan Sekaran.

\section{Pendapatan Keluarga}

Berdasarkan hasil regresi diperoleh nilai t-hitung $=3,130455$ dan diperoleh t-tabel $=1,661$, sehingga diperoleh hasil t-hitung sebesar 3,130455> t-tabel 1,661, maka keputusannya adalah hipotesis nol (Ho) ditolak dan hipotesis (Ha) diterima. Hasil dari uji t tersebut menyatakan bahwa pendapatan keluarga memiliki pengaruh yang positif terhadap pengeluaran listrik rumah tangga di Kelurahan Sekaran. Sesuai dengan hipotesis dan signifikian secara statistik, sehingga dapat dinyatakan bahwa pendapatan keluarga memiliki pengaruh secara nyata terhadap pengeluaran listrik rumah tangga di Kelurahan Sekaran.

Hasil penelitian ini variabel jumlah barang elektronik berpengaruh positif dan signifikan terhadap pengeluaran listrik rumah tangga di Kelurahan Sekaran. Jumlah barang elektronik adalah banyaknya barang elektronik atau alat-alat yang menggunakan tenaga listrik dalam penggunaannya dengan satuan unit. Hubungan antara variabel jumlah barang elektronik dengan pengeluaran listrik rumah tangga adalah positif. Hal ini menunjukkan bahwa dengan adanya penambahan jumlah alat yang menggunakan listrik maka akan mengakibatkan adanya kenaikan terhadap pengeluaran listrik rumah tangga.

Variabel jumlah anggota keluarga merupakan banyaknya anggota keluarga atau pun orang lain yang tinggal menetap dalam satu rumah tangga. Berdasarkan hasil regresi variabel jumlah anggota keluarga berpengaruh terhadap pengeluaran listrik rumah tangga di
Kelurahan Sekaran. Hubungan antara variabel jumlah keluarga dengan pengeluaran listrik rumah tangga adalah positif. Maka dengan bertambahnya jumlah anggota kelurga akan menambah pengeluaran listrik rumah tangga.

Variabel jumlah ruang tidak berpengaruh terhadap pengeluaran listrik rumah tangga di Kelurahan Sekaran. Permintaan atau penggunaan energi listrik suatu rumah tangga tidak hanya merefleksikan pendapatan dan harga, tetapi juga merefleksikan karakteristikkarakteristik demografik dan sosial di mana rumah tangga berada, karena hal ini dapat mempengaruhi fungsi utilitas rumah tangga tersebut termasuk di dalam karakteristik rumah salah satunya adalah jumlah ruang (Anderson, 1973). Tidak adanya pengaruh jumlah ruang terhadap pengeluaran listrik rumah tangga, karena dengan bertambahnya jumlah ruangan belum tentu dalam ruangan tersebut banyak menggunanakan listrik, misal penambahan ruang yaitu gudang dan teras, ruangan tersebut tidak banyak digunakan. Kedua ruangan tersebut listrik yang digunakan hanya lampu saja. Dalam penelitian ini jumlah lampu tidak dimasukkan maka setiap ruangan akan menggurangi jumlah pengeluaran listrik.

Variabel luas bangunan rumah berpengaruh terhadap pengeluaran listrik rumah tangga di Kelurahan Sekaran. Variabel luas bangunan rumah atau luas lahan secara statistik berpengaruh positif dan signifikan sesuai dengan hipotesa awal, hal tersebut menunjukkan bahwa luas banguan rumah berpengaruh terhadap permintaan atau penggunaan listrik rumah tangga. Karena luas bangunan rumah semakin luas akan lebih membutuhkan banyak listrik yang digunakan untuk menerangi setiap ruangan (Wilder \& Willenborg, 1975). Luas bangunan rumah yang 
bervariasi, mendorong pemakaian listrik juga ikut bervariasi. Semakin luas suatu bangunan rumah, maka penerangan yang dibutuhkan akan semakin banyak. Sehingga tingkat pemakaian akan mendorong peningkatan biaya listrik yang dikeluarkan rumah tangga.

$$
\text { Variabel pendapatan keluarga }
$$

berpengaruh terhadap pengeluaran listrik rumah tangga di Kelurahan Sekaran. Hubungan antara variabel pendapatan keluarga dengan pengeluaran listrik rumah tangga adalah positif. Keynes menyatakan bahwa bahwa pengeluaran seseorang untuk konsumsi dan tabungan dipengaruhi oleh pendapatannya. Semakin besar pendapatan seseorang maka akan semakin banyak tingkat konsumsinya pula, dan tingkat tabungannya pun akan semakin bertambah. dan sebaliknya apabila tingkat pendapatan seseorang semakin kecil, maka seluruh pendapatannya digunakan untuk konsumsi sehingga tingkat tabungannya nol. Dalam teori konsumsi dengan hipotesis pendapatan absolut keynes juga menyatakan pendapatan merupakan faktor penentu dari konsumsi. Sehingga hubungan antara pendapatan dengan konsumsi adalah positif.

\section{SIMPULAN}

Berdasarkan penelitian yang dilakukan tentang fator-faktor yang mempengaruhi pengeluaran listrik di Kelurahaan Sekaran, Kecamatan Gunungpati, Kota Semarang, maka dapat ditarik kesimpulan bahwa jumlah barang elektronik, jumlah anggota keluarga, luas bangunan rumah, pendapatan keluarga berpengaruh positif dan signifikan terhadap pengeluaran listrik rumah tangga di Kelurahan Sekaran, Kecamatan Gunungpati, Kota Semarang. dan jumlah ruang tidak berpengaruh terhadap pengeluaran listrik rumah tangga di Kelurahan Sekaran Kecamatan Gunungpati, Kota Semarang.

\section{DAFTAR PUSTAKA}

Arifin, Agus dan Suprapto. 2015. Anaysis oof Production and Consumtion in Hair Artisans at Karangbanjar Village, Bojongsari District, Purbalingga. Dalam Jurnal Ekonomi dan Kebijakan (JEJAK), 8(2): 108125 .

Anderson, K. P., 1973, "Residential Demand for Electricity : Econometrics Estimates for California and the United States”, Journal of Business, Vol. 46, Issue 4, October 1973, pp. 526-532.

BPS. 2015. Jawa Tengah Dalam Angka 2015. Jakarta: BPS.

ESDM. 2009. "Master Plan Pembangunan Ketenagalistrikan 2010-2014 KESDM, 2009: 13".Jakarta: ESDM.

Ghozali, Imam. 2009. Aplikasi Analisis Multivariate Dengan Program SPSS Cetakan IV. Seamarang: Badan Penerbit Universitas Diponegoro.

Gujarati, Damodar and Dawn C. Porter. 2012. Dasardasar Ekonometrika. Jakarta: Salemba Empat.

Kadir, A. 200o. Energi: Sumberdaya, Inovasi, Tenaga Listrik dan Potensi Ekonomi. Jakarta: UI Press.

Mankiw. 2003. Teori Makro Ekonomi. Edisi kelima. Jakarta: Erlangga.

Sari, Agnes Marisca Dian. 2016. Analisis Pengaruh Konsumsi Rokok dengan Kemiskinan di Provinsi Jawa Tengah. Dalam Economic Development Analysis Journal (EDAJ)5(3)

Sugiyono. 2010. Penjelasan Mengenai Variabel. Bandung: Alfabeta.

Sukirno, Sadono. 200o. Makro Ekonomi Moderen. Perkembangan Pemikiran dari Klasik Hingga Keynesian Baru. Jakarta: PT. Raja Grafindo Persada.

Suparmoko. 1998. Pengantar Ekonomika Makro. Yogyakarta: BPFE.

Widarjono, Agus. 2007. Ekonometrika Teori dan Aplikasi. Yogyakarta: FE UII.

Wilder, R. P., and John F. Willenborg. 1975. "Residential Demand for Electricity: A Consusmer Panel Approach”. Southern Economic Journal, Vol. 42, Issue 2, Oct. 1975, pp. 212-217. 